\title{
Nuclear Nihilism, Creating the Soviet Dead Hand: A Necessary Evil
}

\section{Ezra Beudot}

In 1985 Perimeter came online, ready for active duty deep beneath the Ural Mountains. Three duty officers waited with the fate of humanity in their hands, at any moment the system could automatically detect the signs of a nuclear attack on the Soviet Union, based on seismic, light, and over-pressure data. Soviet leadership could be obliterated, and Perimeter would then be ordered to fire off a number of command missiles, which would soar thirty miles above the earth and broadcast launch codes to all the motherland's surviving Intercontinental Ballistic Missiles (ICBM's). Half an hour after Russia died the hardened silo's concrete caps would roll open, (even if their crews were dust) and missiles commanded by dead men would light their motors and roar into the sky, cross the Earth in under thirty minutes, and deliver bright nuclear vengeance to whomever killed their masters. ${ }^{1}$ Even a "limited exchange," of 10,000 megatons worth of warheads would blind every living creature on Earth, blot out the sun, and cause nuclear winter. In this way, the world would end. ${ }^{2}$

Perimeter remains online to this day, constantly collecting and analyzing data, ready and waiting for a war that will hopefully never come. Perimeter may sound like a doomsday weapon, and it may be, especially if an automatic mode does exist. ${ }^{3}$ However, its creation was a long time coming for the Soviet Union, which was on a mission to find the best possible solution for its nuclear command network, and safeguard against potential sudden annihilation. The creation of the Perimeter system was the logical outgrowth of Soviet nuclear strategic planning. It

\footnotetext{
${ }^{1}$ Hoffmann, David E. The Dead Hand: The Untold Story of the Cold War Arms Race and its Dangerous Legacy (Toronto: Doubleday,2009) pg. 154

${ }^{2}$ Kurtz, R. Lester The Nuclear Cage: A Sociology of the Arms Race (Austin: Prentice Hall, 1988) pg.7

${ }^{3}$ Ross Alan Douglas Nuclear Weapons and American Grand Strategy: Essential Pillar or Terminal Liability (International Journal 63.4 (Autumn 2008): para 47
} 
streamlined Soviet nuclear command-and-control systems, eased the burden of responsibility on aging and frightened Soviet leadership, and most importantly, would provide nuclear retaliation in a situation of strategic decapitation, answering Soviet leader's fear of uncertainty with the promise of certain retaliation. The following six primary reasons show that the implementation of the Perimeter system was a logical decision on the part of Soviet leadership, and its continued operation was rational.

This paper will begin with a basic primer on nuclear warfare and the Cold War into which Perimeter was born. The thermo-nuclear weapons of the 1980's dwarfed the weapon that had destroyed Hiroshima in 1945. In terms of explosive yield, a single megaton bomb is equivalent to seventy Hiroshima explosions. Both the Soviet Union and the United States of America maintained thousands of such weapons, mounted onto thousands of missiles able to cross the world in under half-an hour. ${ }^{4}$ In order to deter the other side from ever firing their missiles, each side had to ensure its own ability to respond by maintaining the capacity to totally annihilate the aggressor. This doctrine, adopted by both the Soviets and Americans, is called mutually assured destruction (MAD). ${ }^{5}$ Therefore, both sides had to be able to launch their missiles at their enemy once they received positive confirmation of an incoming attack. This requires an organized, coherent command structure with built in redundancy.

Before the Perimeter system is covered in detail, the historical background it was born into must also be explored. The idea for an automatic or semi-automatic strategic nuclear command system was not a new one in 1984, when Perimeter was first tested. ${ }^{6}$ The Soviet desire for a system with similar qualities dates back to the Khrushchev era. In 1959, Khrushchev

\footnotetext{
${ }^{4}$ Kurtz, R. Lester The Nuclear Cage: A Sociology of the Arms Race (Austin: Prentice Hall, 1988) pg.43

${ }^{5}$ Kurtz, R. Lester The Nuclear Cage: A Sociology of the Arms Race (Austin: Prentice Hall, 1988) pg.129

${ }^{6}$ Hoffmann, David E. The Dead Hand: The Untold Story of the Cold War Arms Race and its Dangerous Legacy (Toronto: Doubleday, 2009) pg. 154
} 
remarked "our rockets will fire automatically," which was certainly false at the time, but highlights the leadership's desire for automatic retaliation. This statement shows that there was an early focus to obtain a quick firing missile. ${ }^{7}$ At the time, the first Soviet inter-continental ballistic Missile had yet to reach operational status, the SS-6 Sapwood. The nuclear command and control system relied on paper dockets distributed to each area command, to be opened in a crisis. However, even from this early stage the foresight of Soviet leadership was exemplified. ${ }^{8}$ Soviet leaders knew they had to make their deterrence a credible threat, and to do that they required a nuclear command and control system which could react quickly and efficiently to any threat.

Another element of this desire for immediate response came out of the negligible strategic impact of anti-ballistic missile systems (ABM) which would not be able to respond to more than an extremely limited attack. The system had trouble with targeting multiple independently targetable reentry vehicle warheads (MIRV). Though the Soviet Union developed and deployed an ABM complex, from as early as 1965 there were serious doubts about its usefulness. Gennadi Gerasimov, pointed out that missile defense is pointless and that nuclear wars are simply unwinnable as "to intercept and destroy all the missiles is simply impossible". 9 Additionally, ABMs became limited by the Anti-Ballistic Missile Treaty of 1972. Furthermore, a protocol added to that treaty in 1974 further limited both sides to only one hundred missile interceptors located at a single site. ${ }^{10}$ As limiting ABMs were being discussed, the Soviet nuclear

\footnotetext{
${ }^{7}$ Catudal, Honore M. Soviet Nuclear Strategy from Stalin to Gorbachev: A Revolution in Soviet Military and Political Thinking (London: Mansell Publishing Ltd., 1988) pg. 166, 167

${ }^{8}$ Thomas B. Chochran, et. al. Volume IV: Soviet Nuclear Weapons (New York: Harper and Row Publishers, 1989) pg. 102 Table 5.4

${ }^{9}$ Catudal, Honore M. Soviet Nuclear Strategy from Stalin to Gorbachev: A Revolution in Soviet Military and Political Thinking (London: Mansell Publishing Ltd., 1988) pg. 192

${ }^{10}$ Catudal, Honore M. Soviet Nuclear Strategy from Stalin to Gorbachev: A Revolution in Soviet Military and Political Thinking (London: Mansell Publishing Ltd., 1988) pg. 174
} 
command and control system, Signal, was being modernized to act faster and more automatically. Signal-M featured a "remote-control button that could be pushed to launch," according to David E. Hoffmann author of, The Dead Hand: The Untold Story of the Cold War Arms Race and its Dangerous Legacy. ${ }^{11}$ This system came online in the mid 1970's and also featured a number of pre-planned attack scenarios, one of which would be chosen based on the perceived nature of the attack. For its part, the research and development of Perimeter began in 1974, the same year ABM limitations were decided on. ${ }^{12}$ Evan as Signal-M was being modernized, another nuclear command system was under development which represented a desire for strategic redundancy in line with the Soviet necessity to keep their deterrence valid.

Before Perimeter the Soviet nuclear policy was to "launch on warning", meaning that if early-warning radars, satellites, and sensors detected an incoming missile attack, Soviet missiles would be then launched in retaliation, before the enemy warheads struck Soviet command and control or wiped out the missile fields. The United States had principally the same policy, and both sides were on a "hair-trigger." Launch-on-warning would ensure retaliation, as the missiles could not be stopped once launched. The Soviet Union and the US were operating on a "use them or lose them," mentality, either launch the missiles or potentially lose everything. ${ }^{13}$ The fallacy is that even if only one side struck the other with a nuclear attack, they would have committed suicide, the initial strike causing a nuclear winter. ${ }^{14}$ This approach came with the serious threat of an accidental nuclear holocaust, as both side's detection systems were prone to displaying false positives. The US system reported over 100 errors in an eighteen-month period.

\footnotetext{
${ }^{11}$ Hoffmann, David E. The Dead Hand: The Untold Story of the Cold War Arms Race and its Dangerous Legacy (Toronto: Doubleday,2009) pg. 154

12 Ibid. pg. 150

${ }^{13}$ Ibid. pg. 8

${ }^{14}$ Kurtz, R. Lester The Nuclear Cage: A Sociology of the Arms Race (Austin: Prentice Hall, 1988) pg. 28
} 
The Soviet system, centered around a constellation of Oka "eye" satellites and the M-10 supercomputer also had a number of false alarms, which could have escalated to nuclear war had it not been for the caution used by the command crews on station. ${ }^{15}$

Perimeter was designed to be above such errors. It required three different points to be certain before it allowed for retaliation; a loss of contact with political and military leadership, seismic, radioactivity, light, and over-pressure data suggesting a nuclear attack on Soviet soil, and that the Perimeter system be given advance permission to fire. Only at that point would the human command team determine whether to fire the command missiles. ${ }^{16}$ The Perimeter system was to provide a number of major benefits over the Signal system, including its level of streamlining and automation, its removal of responsibility from top officials, its departure from the launch-on-warning policy, increased flexibility, and a future-proofing capacity.

The streamlining of Soviet nuclear strategic command was a critical aspect of Perimeter. Before its implementation Soviet command authority had been reliant on the Signal system, which had its first iteration implemented in $1958 .{ }^{17}$ Perimeter would avoid potential problems of confusion and loyalty, rather than having individual missile batteries deliver the order to launch, the command rockets would simply order the missiles out of their own silos. ${ }^{18}$ This eliminated confusion over launch orders; during prior exercises many Soviet officers would attempt to call headquarters back, in order to confirm an affirmative launch order. ${ }^{19}$ This issue highlights the major problem of command disorganization present in the Strategic Rocket Forces, and one

\footnotetext{
${ }^{15}$ Hoffmann, David E. The Dead Hand: The Untold Story of the Cold War Arms Race and its Dangerous Legacy (Toronto: Doubleday,2009) pg. 11

${ }^{16}$ Hoffmann, David E. The Dead Hand: The Untold Story of the Cold War Arms Race and its Dangerous Legacy (Toronto: Doubleday,2009) pg. 152,153

${ }^{17}$ The Signal system was refined and modernized throughout its life, and by Signal-A of the 1980's it had little in common with its initial iteration.

${ }^{18}$ Ibid. pg. 150

${ }^{19}$ Ibid. pg. 152,153
} 
Perimeter would bypass with its smaller duty crew, able to be placed directly in control of all Soviet ICBMs in a time of crisis. ${ }^{20}$ When Perimeter became operational in 1985 the Soviet Union had 1,398 ICBM launchers with between 6,420 and 6,840 warheads. ${ }^{21}$ Ensuring that those launchers could respond to an attack in under half an hour was critical.

Perimeter's ability to streamline the nuclear strategic command-and-control system also helped to remove Soviet top civilian and military leadership from the loop in case of crisis. In turn helping safeguard against the problems of a geriatric leadership and their fear of responsibility. This was an important factor for Leonid Brezhnev, leader of the USSR, who deeply feared ever having to decide the fate of the world, and was terrified of the responsibility inherent in declaring a retaliatory strike. ${ }^{22}$ Additionally, later Soviet leadership were on death's door, and their ability to make sound decisions was permanently in question. Konstantin Chernenko, for example, spent most of his time as a leader bedridden in a hospital, unable to walk, climb stairs, and was close to death. ${ }^{23}$ When these leaders expired there was always some gap between their death and their successor's ascension. This meant there was continuous uncertainty based on the mortality of Soviet leadership, as no one knew exactly when the leader would die. The death of a leader always represented a temporary weak moment in the Soviet strategic command network. Therefore, Perimeter served to alleviate this problem, by being on permanent alert and able to retaliate outside of the conventional command structure.

Perimeter's ability to respond to an attack when the conventional structure had been obliterated allowed it to defeat the possibility of sudden strategic decapitation. Soviet leadership

\footnotetext{
${ }^{20}$ Hoffmann references an event where Soviet forces were put on high alert by accident, but all but a single officer did nothing or called headquarters to confirm whether the orders were genuine.

${ }^{21}$ Thomas B. Chochran, et. al. Volume IV: Soviet Nuclear Weapons (New York: Harper and Row Publishers, 1989) pg. 103 Table 5.4

${ }^{22}$ Hoffmann, David E. The Dead Hand: The Untold Story of the Cold War Arms Race and its Dangerous Legacy (Toronto: Doubleday,2009) pg. 20

${ }^{23}$ Ibid. pg. 145
} 
of the early 1980s feared the speed of American "tactical" nuclear missiles. Especially the Pershing II, which could be launched from within Western Europe, fly at supersonic speeds beneath Soviet early warning radar, and destroy Moscow six minutes later. ${ }^{24}$ Even in such a nightmare scenario Perimeter could assure mutual destruction.

Uncertainty was a driving factor in Perimeter's deployment and it put the fears of leaders to rest in its unyielding ability to respond even after the Soviet Union had been attacked. One uncertainty was the American nuclear command structure. Not all American missiles were under the president's direct control. This included the American nuclear submarines that could launch authorization and at their own captain's discretion. More uncertainty came in the form of Chinese leadership, which after the Sino-Soviet split had poor relations with the Soviet Union. ${ }^{25}$ Their first ICBM was deployed in 1981, the same year their first nuclear ballistic missile submarine came into service. ${ }^{26}$ The People's Republic of China never officially laid out its nuclear weapon's policy, which was interpreted by Soviet leadership to mean that a sudden strike could come at any time and without warning. ${ }^{27}$ In summation, Soviet leaders feared an accidental enemy launch, a rogue enemy launch, and potential third party attack (from the PRC). These strategic uncertainties demanded attention, and the Perimeter system addressed them.

Perimeter not only addressed the uncertainties already present in the minds of Soviet leaders, but it also addressed future concerns. The Chinese were expanding their nuclear capability, adding more warheads and expanding their means of delivery. ${ }^{28}$ High-speed, high

\footnotetext{
${ }^{24}$ Kurtz, R. Lester The Nuclear Cage: A Sociology of the Arms Race (Austin: Prentice Hall, 1988) pg. 20

${ }^{25}$ Coates, Ken "China and the Bomb," Found in China and the Bomb, ed. Ken Coates (Nottingham: Humanities Press, 1986) What Perimeter provided Pg 38

${ }^{26}$ Phillip C Saunders and Jing-dong Yuan "Strategic Force Modernization," Found in China's Nuclear Future ed. Paul J. Bolt and Albert S. Willner (London: Lynne Rienner Publishers, 2006) pgs. 79 and 87

${ }^{27}$ Mediros Evan S. Medeiros "Evolving Nuclear Doctrine," Found in China's Nuclear Future ed. Paul J. Bolt and Albert S. Willner (London: Lynne Rienner Publishers, 2006) pg. 47

${ }^{28}$ Mediros Evan S. Medeiros “Evolving Nuclear Doctrine," Found in China's Nuclear Future ed. Paul J. Bolt and Albert S. Willner (London: Lynne Rienner Publishers, 2006) pg. 48
} 
accuracy nuclear capable cruise missiles were being developed by the United States, which without Perimeter could cause strategic decapitation. High-yield MIRV capable warheads and debilitating EMP (electromagnetic pulse) strikes before the main salvo were also being developed. ${ }^{29}$ The nature of perimeter's automation and timing could counter each of these threats, as the command missiles could be launched after an EMP strike. The location of the command missiles deep within the Soviet Union made them difficult targets for cruise missiles. The depth of the command bunker in the Ural Mountains protected Perimeter from potential attacks. ${ }^{30}$ These bunkers, called shariki (sphere) were the nucleus of the system, and would be where the final decision to launch would be made in case of a strategic decapitation.

Perimeter did have limitations. Hoffmann points out the most critical one in The Dead Hand: The Untold Story of the Arms Race and its Dangerous Legacy, that the command crews, "if well drilled, would naturally push the button," if the Perimeter's short checklist was met. With the fallibility of early warning technology, and the super-computers which analyzed the relevant data. Perimeter could make a mistake. One of Perimeter's designers viewed the system as a "last layer of sanity, the possibility of saying no to mass destruction". This man, Valery Yarynich, believed that even during a nuclear attack these officers might not push the button, because "what's the point in doing it if half the globe is already wiped out."

Both sides attempted to depict the other as monsters, which legitimized their own massive stockpiles of weapons and their policies of deterrence and retaliation. ${ }^{32}$ Serving as

\footnotetext{
${ }^{29}$ Catudal, Honore M. Soviet Nuclear Strategy from Stalin to Gorbachev: A Revolution in Soviet Military and Political Thinking (London: Mansell Publishing Ltd., 1988) pg. 177

${ }^{30}$ Hoffmann, David E. The Dead Hand: The Untold Story of the Cold War Arms Race and its Dangerous Legacy (Toronto: Doubleday,2009) pg. 152

${ }^{31}$ Hoffmann, David E. The Dead Hand: The Untold Story of the Cold War Arms Race and its Dangerous Legacy (Toronto: Doubleday,2009) pg. 153

${ }^{32}$ Kurtz, R. Lester The Nuclear Cage: A Sociology of the Arms Race (Austin: Prentice Hall, 1988) pg.87
} 
nuclear insurance, Perimeter not only added an element of stability to Soviet planning, but also made it easier for Soviet leadership to trust in their ability to respond, providing them with a degree of confidence that they never had before. The Perimeter system was the logical outgrowth of Soviet nuclear strategic planning, streamlining Soviet nuclear command and control (CiC) systems. It eased the burden of responsibility on the old, and terrified Soviet leadership, and critically provided nuclear retaliation in a situation of strategic decapitation. Today, we live in a very different world than the one which precipitated the creation of systems such as Perimeter, and yet the system remains, as not just a bygone relic of the Cold War, but as an operational element of Russian strategic nuclear command. ${ }^{33}$ The Russian Federation and United States both maintain at least a third of their missiles on alert. According to De-Alerting Strategic forces, by Bruce G. Blair, "Thousands of warheads atop hundreds of ballistic missiles," are still poised to annihilate their enemy. ${ }^{34}$ Launch on warning remains a primary strategy of both sides. The equipment designed and deployed in the 1980's remains largely in service, and is now more prone to making false alarms as the equipment ages. This leads to a chance of a "launch on falsewarning," situation. ${ }^{35}$ Perimeter is now over thirty years old.

The Peoples Republic of China now has both a credible deterrent and are intentionally ambiguous as to how they intend to use them. Threats arising from terrorism and cyber-warfare were not considered when Perimeter was designed. ${ }^{36}$ Perimeter was the logical choice for Soviet leadership in 1985, but what use does such a system have today? The existence, and operation of Perimeter is now public knowledge and continues to serve as a deterrent element of Russian

\footnotetext{
${ }^{33}$ Ross Alan Douglas Nuclear Weapons and American Grand Strategy: Essential Pillar or Terminal Liability (International Journal 63.4 (Autumn 2008): para 47

${ }^{34}$ Blair, G. Bruce De-Alerting Strategic Forces (Brookings Institute pr, 2004) pg. 47

${ }^{35}$ Blair, G. Bruce De-Alerting Strategic Forces (Brookings Institute pr, 2004) pg. 48

${ }^{36}$ Blair, G. Bruce De-Alerting Strategic Forces (Brookings Institute pr, 2004) pg. 48
} 
nuclear strategy. The image of three duty officers waiting in their shariki and determining the fate of the world does not belong to a peaceful Earth, and today three officers are awaiting the end of humanity. 


\section{Bibliography}

Blair, G. Bruce De-Alerting Strategic Forces (Brookings Institute pr, 2004)

Catudal, Honore M. Soviet Nuclear Strategy from Stalin to Gorbachev: A Revolution in Soviet Military and Political Thinking (London: Mansell Publishing Ltd., 1988)

Chou En-LI and Government of the People's Republic of China "The First Chinese Nuclear Explosion: Some Statements," Found in China and the Bomb, ed. Ken Coates (Nottingham:Humanities Press, 1986) 41, 48

Coates, Ken "China and the Bomb," Found in China and the Bomb, ed. Ken Coates (Nottingham: Humanities Press, 1986) 11, 14, 38.

Hoffmann, David E. The Dead Hand: The Untold Story of the Cold War Arms Race and its Dangerous Legacy (Toronto: Doubleday,2009)

Kurtz, R. Lester The Nuclear Cage: A Sociology of the Arms Race (Austin: Prentice Hall, 1988)

Mediros Evan S. Medeiros "Evolving Nuclear Doctrine," Found in China's Nuclear Future ed. Paul J. Bolt and Albert S. Willner (London: Lynne Rienner Publishers, 2006)

Phillip C Saunders and Jing-dong Yuan "Strategic Force Modernization," Found in China's Nuclear Future ed. Paul J. Bolt and Albert S. Willner (London: Lynne Rienner Publishers, 2006)

Ross Alan Douglas Nuclear Weapons and American Grand Strategy: Essential Pillar or Terminal Liability (International Journal 63.4 (Autumn 2008):

Thomas B. Chochran, William M. Arkin, Robert S. Norris, and Jeffrey I. Sands Volume IV: Soviet Nuclear Weapons (New York: Harper and Row Publishers, 1989) 